Portland State University

PDXScholar

University Honors Theses

University Honors College

$2-28-2020$

\title{
Maus, Masks, and the Performance of Identity
}

Amie Zimmerman

Portland State University

Follow this and additional works at: https://pdxscholar.library.pdx.edu/honorstheses

Let us know how access to this document benefits you.

Recommended Citation

Zimmerman, Amie, "Maus, Masks, and the Performance of Identity" (2020). University Honors Theses.

Paper 824.

https://doi.org/10.15760/honors.843

This Thesis is brought to you for free and open access. It has been accepted for inclusion in University Honors Theses by an authorized administrator of PDXScholar. Please contact us if we can make this document more accessible: pdxscholar@pdx.edu. 


\title{
Maus, Masks, and the Performance of Identity
}

\author{
by \\ Amie Zimmerman \\ An undergraduate honors thesis submitted in partial fulfillment \\ of the requirements for the degree of \\ Bachelor of Arts \\ in \\ University Honors \\ and \\ English
}

Thesis Adviser

Elisabeth Ceppi, Ph.D.

Portland State University

2020 


\section{Maus, Masks, and the Performance of Identity}

Questions of identity preoccupy modern American culture and society. At its most basic, identity is how one views oneself-the character traits and aspects of personality that constitute one's personhood in light of cultural value systems-and how one reveals that personhood to the outside world. But this definition belies the complexity of identity, which comprises both fixed characteristics such as skin or eye color and ones that are more fluid, like profession and sense of humor. Debates about the fluid and fixed aspects of American identity have figured heavily in scholarly and public discourses about the relative values and terms associated with multiculturalism, representation, and diversity. Scholars like Charles Taylor, Kwame Anthony Appiah, Saidiya Hartman, and Jodi Melamed ${ }^{1}$ have illuminated the sometimes contradictory duality of identity and the lived experience of it in America. Americans demand a universalizing empathetic ethics while insisting on a celebratory stance regarding our differences; we downplay differences to find common sites for empathy and desire to celebrate individual identity by highlighting those same personal and cultural differences. We continue to hold that identity is a both/and rather than an either/or, despite the contradictions and concerns this raises.

A classic trope in cultural productions that allows us to interrogate the complexity of identity is the use of masks. Donald Pollock, in his essay "Masks and the Semiotics of

\footnotetext{
${ }^{1}$ Although not within the scope of this paper, several critics helped contextualize my thinking. Further reading on the concepts of multiculturalism, neoliberalism, identity, diversity, and representation: Saidiya Hartman, Scenes of Subjection: Terror, Slavery, and Self-Making in Nineteenth Century America (Oxford University Press, 1997); Jodi Melamed, Represent and Destroy: Rationalizing Violence in the New Racial Capitalism (University of Minnesota Press, 2011); Charles Taylor, Multiculturalism: Examining the Politics of Recognition (Princeton University Press, 1994); Kwame Anthony Appiah, The Ethics of Identity (Princeton University Press, 2004).
} 
Cultural Identity," contends that cultures themselves assign certain character traits to masks, and that those masks can take many forms depending on how each culture requires the masks to function (581-2). Members of communities agree, or collude, to invest masks with the power to transform the identity of the wearer. In general, the identity markers invested in masks can be considered a useful tool for openly engaging in desired community, but often masks are also a method for hiding or disguising a perceived flaw in our private selves. What are the ways in which masks, as symbols of shared value systems, facilitate belonging? What are the ways in which masks, as public cultural requirement, are oppressive? As a signifier of identity, what happens to our private selves when we use masks as a necessary means of survival?

Art Spiegelman's graphic novel Maus powerfully explores the concept of identities as masks and the conscious act of masking. In 1992, Spiegelman won a Pulitzer for his biography-framed-in-memoir about his parents' Holocaust survival and Art's subsequently fraught relationship with his traumatized father. Characters in both Maus I and II use masks to hide their identity: in the first book, Art's parents attempt to escape from Nazi authorities by disguising their mouse/Jewish identity; in the second, Spiegelman and several other humans don animal masks to project different national and ethnic identities. However, there are problems inherent in his attempt to define identity as both fixed (Maus I) and changeable (Maus II) as it is represented by masks in Maus, since identity is amorphous, both in Maus and cultures at large. While a cursory reading of Maus could indicate that Spiegelman considers ethnic identity to be fixed, his varied use of masks as pliant signifier of ethnic representation points instead to the nuanced and contradictory nature of the performance of identity within American culture. This essay will explore 
Spiegelman's use of masks as representatives of ethnic identity, the ways masks function as symbols in culture, and the persistence of the white supremacist framework for legitimating identity in American culture.

The frame proposed within Maus' masks is purposefully troubling, drawing from early $20^{\text {th }}$ century racist stereotypes and fascist propaganda, placing before a broad audience the question of not just Jewish identity, but of American self-awareness. Spiegelman's interest was in creating commentary rooted in acknowledgment of his artform's participation in white supremacist propaganda of the early $20^{\text {th }}$ century. American cartooning of this era, political and entertainment alike, perpetuated stereotypically racist imagery of black Americans-a practice which Spiegelman wished to address directly (Loman 551). The reductive quality of the pre-World War II-era cartooning emphasized a stereotyped identity as fixed, a troubling notion for Spiegelman. And although he felt that the details of the injustice of the black American experience were not his to extrapolate, Spiegelman recognized the common thread of racist, reductive identity stereotypes, weaponized by white supremacist regimes justifying genocide. I believe Spiegelman saw his choice to politicize simplistic cartoon animals as subverting the weapon of the oppressor, making it an act of anti-racism and solidarity.

To interrogate the applicability of Spiegelman's critique to a broader project of antiracism, I will propose connections and through-lines between his work and poet-critic Claudia Rankine's explorations of black American identity in Citizen. Rankine's consideration of the "performance of blackness" is in direct conversation with W.E.B. Du Bois' concept of "the Veil" and Frantz Fanon's explication of the black Self reflected in the white gaze. These critics denote how racism works to split black Americans' identities into 
public and private selves and provide a crucial point of comparison between Spiegelman and Rankine's depictions of masks, identity, performance, and audience. In linking the work of black writers such as Du Bois, Fanon, and Rankine to the anthropological and sociological work of Donald Pollock and Stanislav Kolář, I hope to present the contradictory mask usage in Maus as a lens through which we can view the difficulties of cultural identity in America.

\section{MASKS IN MAUS}

As Pollock explains in "Masks and the Semiotics of Identity," for masks to function everyone involved must agree that masks are signs which contain or symbolize a fixed set of ascribed character traits (584). As illustrated by Spiegelman in Maus, this agreement indicates cultural collusion and can be a mode of ethnic identification. For example, when Art's parents put on pig masks in Maus I, the other characters immediately respond to them as if they are Polish. There is risk that Anja and Vladek will be discovered and apprehended by Nazis and the audience is invested in the masks as successful disguise. At first glance, animal and mask imagery appears to be a simple way to present sticky ethical material in a straightforward and digestible manner.

Both volumes of Maus utilize masks as signs, but with differing functions. The consistent message in Maus I is that even while wearing pig masks, Spiegelman's parents are still fundamentally mice. But when he takes up masks and the fluidity of identity in Maus II, Spiegelman has subverted his own premise: in an extreme shift in presentation, humans are the basic identity and animal embodiment is solely in the form of a flimsy mask. As symbols or semiotic signs in Maus, animal masks have multiple meanings, worn by 
characters to inconsistent effect. Representations of personal identity fluctuate in Maus, though Jewish cultural tradition is based on a shared, fixed narrative. Fluidity is disruptive: we are left with the uncomfortable premise that ethnic identity can be changed as easily as putting on a mask (Ma 118).

In the first volume of Maus, Spiegelman clearly signals to readers that mouse equals Jew and pig equals not-Jew: identity is fixed. By creating this shorthand communication for the reader through his graphic choices, Spiegelman cannot sidestep being reductive and problematic. The simplicity of humans-as-animals is an attractive solution for presenting complex, distasteful, or predatory human behavior, thus making lighter work of the otherwise heavy labor of explaining contradictions (Loman 459-560). I believe Spiegelman was aware of the imminent failure of his metaphors to encompass the difficulty of his subject matter. There are no simple solutions for addressing a subject's need for cultural identification while simultaneously acknowledging racism's appropriation of ethnic generalities. Humans-as-animals is a double-bind for an audience willing to note how ethnicity-based characteristics are both generalities when applied from the outside and specificities when claimed from the inside.

In Maus I, Anja and Vladek's fixed identities as Jews could be seen on the outside: mousehood. In order to hide their mousehood, which would get them killed, they purposefully place masks over their faces to appear to be Polish pigs (137). At this point Spiegelman is defining Jewishness, or at least Anja and Vladek's Jewish identity, as fixed in the body and visible on the exterior, known and recognizable within their community. What the pig masks represent is an effort to appear Polish to strangers, which could mean style of dress, language, accent, dialect, or nationalistic sentiment. Although the first time 
we see physical masks is when Vladek lies to a Polish conductor on a train to hide from German soldiers, we are introduced in-depth to the concept of mask-wearing when Vladek and Anja are forced to wear them to pass as Poles while trying to escape the Srodula ghetto (Maus I 64; 125-55). They must wear masks to barter for food, convince other Poles to shelter them, and avoid Nazi authorities. Anja and Vladek, wearing pig masks, wander the countryside surrounding Sosnowiec in search of hiding places and then attempt to escape to Hungary before being captured. The penultimate scene of the first book shows German Nazi cats pulling the pig masks away to reveal their identities as Jewish mice prior to sending them to Auschwitz.

For the sake of Spiegelman's narrative, pig masks in Maus I represent a set of secular, Polish character traits recognizable to the community of Sosnowiec during World War II. But are these traits recognizable to outsiders? Would these traits be ascertainable now? According to Pollock, different cultures use masks to contain symbols of identity, and these symbols are commonly recognized within cultures as character traits, or identity markers. However, identity—how any given culture defines personhood-is never static (Pollock 584). Over time, modifications to collections of identity markers are made, with some traits foregrounding and others fading away. As Pollock explains, a collection of these markers—including names, property, physical adornment, possession of certain objectscan be reliable means for discerning a person's identity and/or role within a given culture. The situating of symbols of identity within a culture's own lexicon, called an "index," requires us to acknowledge signs of identity as fluid or changeable if those indexes are compared across cultures and over time (582). While a marker may be fixed and ascribed to a particular societal role in one culture, that same marker becomes fluid within 
comparative sociological or temporal conditions. To recognize when someone is wearing a mask, we must understand the significance of that mask within its particular index. Spiegelman creates his own index within the Maus collection by first establishing a fixed set of identity images in Maus I. For the purpose of Maus I, this index states that mouse/Jew identity is fixed in the body and the pig/Pole identity is fixed in the mask; identity markers assigned to the body and the mask do not change or shift when the mask is worn or discarded. The image of Art's parents wearing pig masks over their mouse faces holds meaning for readers, not simply because we understand that Spiegelman is using masks to symbolize identity, but because he is establishing precedent. Spiegelman is telling us that 'animal masks hold identity characteristics' and 'animal masks can be worn and taken off at will.' Masks work because there is a set of ascribed characteristics that signal a role in society being played, like an actor in a play (592). As readers, we believe that Anja and Vladek were able to disguise their identity as Jews through play-acting as secular Poles. When Spiegelman uses masks to symbolize his parents' play-acting or costuming, his audience automatically understands he is signaling that role play. Believability of roles, or the efficacy of masks, depends on the amount and type of signals included in the costume/mask and the willingness of the participants/audience to suspend their disbelief that the actor they are watching is not actually the character being portrayed (Pollock 5845). The reader in Maus I agrees to the collusion of the role-playing because the roles within Spiegelman's index are classically familiar-the predator/prey motif represented by the animal choices is uncomplicated on the surface.

By introducing a more fluid use of masks in Maus II, Spiegelman changes the index's rules he established in Maus I. Instead of animal characters wearing animal masks, humans 
wear animal masks, suggesting an entirely different masking function. Masking in Maus II proposes that baseline identity is undefined and ethnic or cultural identity resides only in the masks one chooses to wear. Spiegelman's struggle with self-doubt regarding his own sense of Jewish identity is echoed when he shifts the masks' function without explaining the source of the inconsistencies in the imagery's meaning. Destabilizing the function of masks within Maus II expands the discourse to include doubts about American culture's concepts of identity and representation as well as Spiegelman's doubts about his own ability to adequately address such a complex issue.

Maus II opens with a discussion between Art and his girlfriend, Françoise, about his choices of ethnic identity as it applies to animal representation in Maus. Art suggests that his choices are generalized, but that all Jewish characters-converted or otherwise-would be depicted as mice. While the audience of the first book would therefore expect to continue to see Spiegelman as a mouse, he instead begins the second chapter of the second book with an image of himself as a human, wearing a mouse mask, presiding over a pile of dead mouse/human bodies (Maus II 41). Over the next few pages he details his guilt regarding success and identity: becoming financially and critically successful from art based on others' trauma feels like exploitation and gives the reader a sense that he doesn't consider his own Jewish identity to be authentic. This is reinforced by reporters and journalists attempting to interview him, all with their own agendas of exploitation, depicted as humans wearing different animal masks as ethnic or cultural identifiers. They are interviewing him in his art studio, no one seeming to notice the bodies of murdered Jews rotting underneath their feet. 
Masks in Maus II serve the purpose of symbolically containing meaning beyond simple disguise: each character is projecting an identity twofold in this sequence. First, the characters are interacting with each other as if they are not wearing masks, tacitly agreeing to accept the identities represented by the masks (Staub 4). Second, although Spiegelman rarely directly addresses the reader in the books, here he faces the audience and asks us to examine our own suspension of disbelief, pushing the metaphor from something palatable (animal menagerie) to something more disturbing (humans/animals). The disruption of the story is evident on the page. Suddenly the analogy is purposefully exposed to the reader as problematic: mice are Jews (what makes a Jew?) and pigs are secular Poles (this is visible externally?) and dogs are Americans (only if born there, but not always?). The reader is asked to examine which characteristics we have chosen to ascribe to the personhood of Germans, Americans, Jews, et al., and-as a reader-I must consider my own readiness to ascribe generalized character traits to others. I think I understand what masks symbolize in Maus I, then Maus II undermines any certainty.

When Spiegelman addresses the reader in Maus II, speaking as a human from behind a mouse mask, the precedent established is subverted and the index of Maus I is destabilized. People use masks under the assumption is that it is meaningful communication: a message is being broadcast to an intended audience with a shared lexicon (Pollock 582). The audience receiving the message knows the mask-wearer's actions have a two-fold intent: to conceal what identity is present originally and project the new identity. Mask-wearing "signals the disguise of identity; in reality it may fail to conceal the identity of the wearer, but its success depends upon the familiar kind of suspension of disbelief through which the 'theater effect' is achieved" (Pollock 585). In the scene in his 
artist studio, by portraying himself as human instead of a mouse, Art signals the readeryou and I are the same.

The key issue, according to Staub, is that "Maus clearly suggests that that identity can never be understood as self-evident; Maus works continually to disrupt comfortable assumptions about where the differences between people lie" (4). Like the reader, like the reporters, like Pavel (his therapist), in this sequence Art is human underneath his identity mask. But this sameness is accompanied by unease; the disruption is keenly felt when each of the characters in Maus II, Chapter 2, use masks for disparate purposes (42). Spiegelman's imagery here says that while there is common human identity underneath the masks, the masks themselves indicate intentional differences. The clearest example is when, within a span of a few pages, three human characters wear mouse masks: Art (Jewish, American, secondary Holocaust survivor), reporter (Jewish, Israeli[?] American [?]), and Art's therapist Pavel (Jewish, Holocaust survivor, Czech-American immigrant). In attempting to find a shared, fixed lexicon between the characters' mask usage, there is some overlap but no perfect alignment. Each of these mouse masks, worn by different humans, contain varied sets of amorphous identity markers, yet are represented by an identical image.

The disruptive quality evident in masks containing multivalent identity markers seems to align with Spiegelman's own unease with identity and the implication of responsibility that it bears. In Maus II, when drawn as a human, Art wears a mask, indicating his discomfort with identity questions and his acknowledgment that notwithstanding this unease, he bears the markers of Jewish identity; the historical gravity of the Holocaust and the remembrance of Jewish suffering are markers that have formed into something widely recognizable as part of Jewish identity (Loman 566). When 
American culture assigns personhood markers to masks, we say, both you and I agree that these characteristics belong to this identity. We suspend our disbelief that the person under the mask is anything less than fully inhabiting the mask they have put on; masks work only if collusion assumes a mutual understanding of those markers (Pollock 592). Maus II diverges widely from Maus I on this point, because Spiegelman calls into question the intent of the mask-wearer: the same mask can hold multiple meanings based on the wearer's intent and the interpretation of the audience.

The effect of masking in both Maus volumes—the collusion between the audience and Spiegelman, as well as Spiegelman and himself-creates some dilemma. The audience agrees to collude with a narrative of specificities: humans drawn as animals, animals reacting as humans, animals using the artifice of masks, animals sophisticated enough to participate in atrocity and survival. And yet, Spiegelman's mice characters embody the choice to emphasize stylistic generalities. Kolář points out some complicated overlap between the lack of distinct characterization of individuals and the necessity of the audience to interpret animals as humans (90). To say that identities are singular in nature and can be represented in their entirety by animal characterization or mask-wearing is reductive and troubling, but Spiegelman acknowledges this problem: "You can't help when you're reading to try to erase those animals. You go back, saying: no, no, no, that's a person, and that's a person there, and they're in the same room together, and why do you see them as somehow different species? And, obviously, they can't be and aren't and there's this residual problem you're always left with" (qtd. in Staub 4). Thus is located the crisis of masking in Maus II: masks require collusion, and further, that requirement works to 
eliminate personal agency. An observer constructs an identity for the mask-wearer based on projected assumptions; humans are not blank screens.

Noticeably, the mice do not have differing facial features or body sizes beyond agebased representation; there is a monolithic rendering in the image-most effective during depictions of crowds, where the sheer number of identical mice in camp uniforms reiterates the horrifying scale of what happened during the Holocaust (Kolár 90). Perhaps the lack of distinct renderings levels an indictment of neutrality Spiegelman's audience may be harboring. By providing a blank canvas, Spiegelman allows the reader a way to project their own expectations and feelings onto the characters, rendering the mice recognizably human because they have been imbued with the reader's own personality. Monolithic representation of mice is disturbingly reductive and plays a dual role: the characters, though blank, are meant to tell an historically accurate, though generalized, human story. The mice act, talk, and dress like humans; they have human motivations (Staub 4). As a function of fictionalized narrative, this is a useful mode of inviting investment and empathy on the reader's part. Enacted in reality, however, this type of projection of self onto another is problematic and leads to gross assumptions.

What makes a mouse an accurate depiction of a human? It certainly isn't the way the mouse actually looks. No-it is the evidence of the trauma as it is enacted on the mice and their reactions to the trauma that convinces us of their humanity (Kolář 91). The mice contain-mask-like-a recognizably empathetic everyperson character as well as our culture's expectations of that character's reaction to the trauma of the Holocaust. The generic response to trauma portrayed by Maus' mouse-container/masked-human imagery proposes both universality and specificity simultaneously, calling the reader's attention to 
the identity conundrum. As Kolář notes, the predator/prey motif was not accidental and directly confronts racist propaganda which states that "those people" are all a certain way, or all have uniform characteristic features, a flattening of identity which creates monolithic understandings of ethnicity and culture (90). And while critique of such propaganda is necessary, in constructing trauma as mode of humanization, Spiegelman reifies trauma as generalized identity marker.

While Spiegelman's choice to engage these narratives directly is no doubt subversive and clever, there is a failure in the graphic symbolism of masks that leaves us with unanswered questions. What exactly are Jewish character traits? How does one externally represent internal, or privately-held, cultural beliefs that inform identity? Are identity masks interchangeable? Are there any markers that remain fixed, or are they all ultimately fluid? Who decides? Assignation of identity from the outside is troubling when the personal agency of the masked person is in question. In Maus I, Anja and Vladek, though in a desperate situation, seem sure of themselves and the composition of their identitythey have agency in the masking actions they take. In Maus II, Art is isolated, panicked and bewildered about identity—he views those around him as charlatans, lacking substantive selfhood. Masking in Maus II is less a concrete method of survival and more an exercise in the expected performance of ethnicity.

The stark ugliness of the cat and mouse cliché is, of course, on purpose. Portraying Germans as cats and Jews as mice is a deliberate nod to both early American racist cartoons and to Nazi propaganda (Loman 552). Correlations between vermin and entire people groups depend on reductive thinking to proliferate racist ideas of "other"-ness and essentialist hierarchy. The referent culture creates a framework which uses structural tools 
of generalized and oversimplified cultural identity markers to promote and rationalize the predatory, animalistic nature of such declarations. As Kolář suggests, the relationships between "perpetrators, bystanders, and victims" can be aptly explained through animal symbolism because the predator/prey imagery is so appropriate (88). However, the danger inherent in investing in such symbolism is that it can veer into the very territory Spiegelman is criticizing (Loman 560). By acknowledging how handy it is to name and depict certain characteristic identity markers in reductive form, thereby distilling identities into tools, units, or badges, we buy into the framework that provides the racist apologetics we seek to counteract. In short, the very elements that individual cultures seek to celebrate as unique and special are the same elements that racist ideology weaponizes. Spiegelman knew in choosing cats and mice that he would be invoking this dynamic; depicting such historically relevant predator/prey symbolism took cliché material and infused additional moral dilemma (Staub 4).

\section{PERFORMANCE OF IDENTITY}

Critique is valuable only so much as we are willing to examine its teleological consequences. Taking the work of Maus as it applies to Jewish identity and extracting basic truths of same-as and different-than, must in turn lead somewhere. I believe this shift in application must direct us to the structural, systemic white supremacy inherent in the American requirement of cultural performance of identity for black, Indigenous, and people of color. If, drawing from Pollack, the white gaze can be considered the index, then whiteness is the referent and any alterity would be considered the performance. Throughout this paper the term gaze is applied. By this I mean to invoke the questions: 
From whose perspective is evaluation drawn? For whose benefit is identity being performed? Utilizing a global, post-colonial perspective, we then continue to discover and deconstruct the American proclivity toward the white, European, male, wealthy, heteronormative point of view. Once we acknowledge the pervasive quality of this gaze, we understand how what American culture considers normal is not, in reality, universal.

In her essay Under Western Eyes, Chandra Talpade Mohanty uses the term referent to signify a construct with a certain set of distinctions where a specific group is privileged as the norm (261). Of course individual cultures will have their own constructs of normative values and behaviors as it applies to that culture, but it is when the gaze is directed outward through the lens of these values that we see evidence of referent-based judgments. The referent culture, or referent gaze, is the one from which the assessment originates. For example, from a traditional feminist standpoint, Mohanty explains, the average third world woman has a set of essential traits: ignorant, poor, uneducated, tradition-bound, family-oriented, victimized, etc.; such traits are in stark contrast to the Western sense of the empowered feminine self: educated, modern, self-determination, bodily autonomy, etc (261). A clear sense of the referent culture surfaces when the embedded value system is revealed upon examination and in contrast. Essentialist understandings of cultural or ethnic identity traits underscore the limitations of any referent culture's understanding of another, while also misrepresenting the nuanced complexity of the internal discourse within the observed culture. Depending on the originating point of view, the character traits that comprise identity can be cause to disparage or cause to celebrate. 
Pursuant to this dynamic is perhaps the primary American dilemma: crafting our sense of identity from, against, and within the referent point of view of the white gaze. The dilemma this creates for non-white Americans is evident in performative masking, resulting in a splitting of self into a public and a private self. In The Souls of Black Folk, W.E.B. Du Bois famously refers to a double-consciousness he dubs "the Veil," a concept he explains as the self-conscious awareness of black people in relation to white people. $\mathrm{Du}$ Bois defines the Veil as such:

It is a peculiar sensation, this double-consciousness, this sense of always looking at one's self through the eyes of others, of measuring one's soul by the tape of a world that looks on in amused contempt and pity. One every feels his two-ness, - an American, a Negro; two souls, two thoughts, two unreconciled strivings [...] (2) Concurrent to the idea of the Veil, an image close to that of a mask, is a necessary schism of the self, where one is aware of a Self as autonomous entity, yet hidden away, and another self that is conceptual and on display (Fanon 94). Not only does this self-splitting serve to undermine the stability of the black American concept of self, but also it demands the labor of response to the perceived expectations of the referent society. Black Americans, according to Du Bois, must invest in the self they display—the public or performative selffor they are critically conscious black Americans are in a state of near-constant surveillance (6). Looking out from behind the Veil, from behind the mask of performative blackness, black Americans are trapped by both the necessity of wearing the mask for survival and by the ever-changing signifiers that comprise the black American identity (Fanon 90). Being black does not necessarily change, but what it means to oneself and to others to be black in American culture changes in frustrating and sometimes fatal ways. 
One explanation for the contradictory notion of fixed and fluid identity found in Maus' masks is the existence of dual public and private selves as proposed by Du Bois. This concept, picked up by Frantz Fanon and discussed elsewhere in this paper, is a method for explaining the confusion of identity created by the demands of colonialism, white supremacy, and slavery. The legacy of slavery is seen by Fanon as having a splitting effectforcing the slave (and later the free person) to don a figurative mask comprised of expected character traits while disguising the inner self (Fanon 90-1). Masking of one's true nature, disavowing common human reactions which would elicit grave punishment, and presenting to the white observer the person they wished to see, all became life-saving skills for the slave and colonized subject alike. This ties Du Bois, Fanon, and Claudia Rankine together: the breakdown of the black subject's own understanding of the self, the terrible dilemma of having a true private Self unobserved and unacknowledged by the outside (white) world, while feeling forced, in mortal fear, to wear a mask that other (white) people expect to see.

This mortal fear is also illustrated in Book I of Maus, when Spiegelman's parents wear secular Polish identity masks in an attempt to flee the Nazi regime in World War II. Here, the difficulty of defining what constitutes culturally comparative fixed and fluid identity characteristics must be foregrounded. Is Spiegelman drawing equivalencies between the Jewish and black experiences, or is he attempting a more universalist approach to questions of identity? In the case of Du Bois or Fanon, a straightforward interpretation of the Veil's double-consciousness can be situated in an observable measurement: skin color. Defining who is black and who is white is not my focus here (although, of course, colorism is observably rampant globally and race-as-genetic state has 
long been debunked), but Du Bois and Fanon acknowledge blackness, among other factors, as a fixed and observable state of skin color (Fanon 95; Du Bois 2). For Spiegelman, however, we must question whether the shared state of mortal fear is enough to elide the obvious: what are the fixed signifiers of Eastern European Jewish identity? What about external appearances required Vladek and Anja to have to "pass" as secular Poles in their attempted escape? Can there really be an equivalency drawn between the plight of the Jew in Nazi-era Poland and the black American emerging from the spectre of slavery?

These questions bring me to Claudia Rankine's text Citizen and her commentary on the discordant material conditions of black Americans within a white supremacist referent culture. Rankine explains how the term John Henryism has come into common use in the medical field as a way to reference the stress-related physiological consequences of people's exposure to racism (11). The folk tale surrounding John Henry, a black American railroad worker, can be considered a classic tragedy, grimly outlining the repercussions faced by those attempting to prove their worth in a system constructed for them to fail. Henry sets out to prove that he is more productive at setting train tracks than the new steam-driven drill, boasting that he is so strong and fast that he can beat the drill in a competition. Shortly after winning the competition, Henry succumbs to a mysterious illness and dies. Legend has it that, in pushing his body's potential past its capacity, Henry's heart gave out from the stress (Polenberg 149). Rankine likens this to the bodily evidence of black American's attempts to achieve visibility in a culture intent on erasure (11).

To set the scene for how erasure works, Rankine invokes her personal experiences to make the case for the ubiquity and frequency of micro-aggressions. The phenomenon of John Henryism dictates that the black friend, when sitting down to lunch with the white 
friend, already carries the burden of the prescribed roles and power dynamics of their historical relations (14). The black friend will have to actively put this awareness aside when interacting with their white friend, whereas the white friend may be oblivious to their friend's additional labor. In this scene, the black friend will tend to observe differences in the attitudes of waitstaff when dealing with the white friend versus them. For the white friend it may not register that when they are handed the check at the end of the meal, the assumption is they are the financially reliable of the two. Generally, the white friend is accustomed to this assumption-it does not feel notable; they are usually given the benefit of the doubt, so this is not an aberration from the norm. But the experience is, for the black friend, a clear example of micro-aggression and puts stress on their ability to interact with their white friend without resentment. Again, the white friend is unaware because of the commonness of the occurrence. The black friend is reminded of not just the personal history of these micro-aggressions, but the cultural historical significance of the occurrence (Rankine 14). The power hierarchy has been reinforced circumstantially, subtly prescribing certain roles for each friend to play based on the expectations of the waitstaff. The erasure committed when the waitstaff ignores the black friend's presence is then compounded by the work that must be done when the black friend explains to the white friend the experience-a singular example of a collective and pervasive issue.

Where this intersects with masking is clear: if one way for Rankine's black friend to avoid John Henry-levels of exhaustion is to disappear, how better to disappear than behind a culturally acceptable public persona? First the erasure, then the added effort of visibility. It makes sense when Rankine suggests that many people of color find the experience of wearing a recognizable mask to be the simpler task, or at least the task to which they are 
resigned. When faced with being invisible, some people choose to respond by cultivating or leaning into a stereotypical, reductive persona in order to avoid erasure (Rankine 35-6). This double-bind is explored by an artist Rankine features in Citizen, a performance artist named Jayson Musson who vlogs as the character Hennessy Youngman. Musson's Youngman persona is a performance of "blackness" based on his assertions of our culture's expectations of said "blackness" and exemplifies the difficulty of attempting to metabolize rage as a black person in America (Rankine 23; Youngman). As Pollack says, for a performance to be successful, both actor and audience must collude regarding the significance of the portrayal. Roles are largely predetermined within the referent cultural index and the "Angry Black Man" mask is an apt example of such predetermination.

To contextualize the Youngman character, we must first acknowledge that black anger exists as a direct response to the black experience in America and that it is a reasonable response to such an experience. It is not unreasonable for black Americans to be angry about the oppression and racism that comprises daily existence in our country, and for that anger to be fashioned into a recognizable persona. In part, this is the expectation of referent culture: to see the Other align with their assigned or predetermined culturallyappropriate identity. Black identity within the white supremacist referent culture becomes amplified into caricature, as seen in minstrelsy and blackface cartoons of the early $20^{\text {th }}$ century: glaring illustrations of masking. A less obvious form of this same praxis is the flattening of black males' available identity markers or character traits into a handful of acceptable, institutionally-recognized options. In response, Youngman introduces the "Angry Black Man" into the artworld as subversive performance, as persona, as mask, but most importantly as self-aware commodity (Boucher). This persona embodies the elements 
white America considers threatening, channeling rage into a commodified art persona that can be picked up and used at will. After incorporating_or depositing—anger, distrust, and desperation into the construction of such a persona, the resulting mask can theoretically also be discarded when needed. Here, I would like to emphasize commodification as the process by which erasure of the artist, either willingly or reluctantly, takes place. In the case of Spiegelman's fraught studio scene-another notable instance of commodified art symbolism—performance of identity on demand is made repulsive.

In such an example, what differs here between Youngman's performance of blackness as critique and Spiegelman's Jewish mouse masks in Maus II? Both project a set of identity markers, comprised of the traits our culture has colluded to ascribe to black Americans or Jewish Americans. Historically, the pressure to assimilate or performerasure of a sort in either case-has applied to both cultural identities. As a modern American problem, anti-Semitism and anti-blackness form scaffolding in the same referent structure, one that requires performance. In Black Skin, White Masks, theorist Frantz Fanon spends time considering how the multiple requirements of prescriptive identity, what he refers to as an overdetermined state of being, differ when comparing the Jewish and black experiences. Fanon, discussing Sartre's views, sees the Jewish stereotype as located in acts and behaviors, which come to light only over time. The observer in this case can "wait and see" if their perceptions of the Jewish subject are true or false. Therefore, the overdetermination is based on interior traits: Jewishness is located on the inside (qtd. in Fanon 95). Here, the question of Vladek and Anja's pig masks—-the work the masks are supposedly doing to disguise their Jewishness—and the unease with which I approach the idea of an exterior Jewishness, comes to mind. By comparison, Fanon concludes that his 
blackness is a fixed trait located in his physical appearance: "I am overdetermined from the outside" (95). By possessing a character trait visible from the outside-skin color-and therefore being irrevocably "othered" within white referent culture, the black Self is stripped of the ability to self-determine. The performative mask of blackness, projected by the white gaze and disavowed by the black Self, becomes the only seat of agency in this case. The white Other offers one mode of visibility: to accept interpellation through the assumption of the construct of blackness.

For Fanon, black identity is defined through its relation and contrast to the white gaze. The white gaze, also referred to by Fanon as the "Other," projects an image of the black self to the black self, depicting a mutated set of characteristics with which the white gaze has constructed black identity. The black person sees this image-the construct of their self—as a third party, signifying an ontological moment for the black Self (90). Upon realizing the Other is this projection's source, the black Self rejects as unrecognizable the construct presented to them. However, the seed of such knowing has been planted and awareness, once activated, cannot be deactivated—the black Self becomes burdened with double consciousness and forever looks out from behind the Veil (Du Bois 2). Since referent culture, the dominant white European colonizer culture, is reluctant to recognize black identity as it is defined by the black Self, Fanon asserts that external acknowledgment of black self-definition must be forced (95). Heavy with awareness of being unrecognized, the black self steps forward into the full light of the white gaze with the intention of emphatic self-fashioning.

If the relationship of dependency outlined above is correct, and the black sense of self is automatically constructed via the white gaze/referential index, then black identity 
also becomes a performance for the benefit of the watcher. Not only does the white gaze negate and collapse the black ego as if it never existed, but the black Self then receives the imperative to collude with the construct of acceptable persona in order to be seen (Fanon 132). Navigation while inhabiting this persona becomes isolating when, within the referent culture, black-ascribed character traits are objectified by the white gaze. The frame of reference becomes an exhausting game of comparison, where Fanon says blackness is a form of measurement within black culture. Blackness, objectified, places black people in competition with each other for validation (186). Objectified, blackness becomes a set of character traits to inhabit and emphasize as means for visibility, even if it means further reliance, isolation, and abjection. As the Youngman character demonstrates, to be seen and validated within such an incentivized culture, the black self must perform a prescribed and interpellated form of blackness.

\section{CONCLUSION}

At first, masks seem like a simple way to represent a set of ideas, but for masks to work, both the wearer and the observer must agree on the meaning of the symbol. When wearing pig masks in Maus I, mice represent a fixed state of Jewish identity disguised as another fixed state of ethnic or cultural identity. How Spiegelman situates the character traits of Jewish identity—and how societies internally communicate what aspects do or do not comprise ethnic or cultural identity—is through constructing a recognizable, shared framework called an index. By participating in masking, members agree that masks hold specific combinations of markers and that society consequently expects the wearer to publicly perform the role assigned to the particular mask. When identity markers are fixed 
and generally agreed upon, as in Maus I, the shorthand communication between performer and audience is simple and smooth. The white coat worn by a medical professional in a hospital generally correlates to an expectation of medical expertise, i.e., if you are a doctor, I can trust you to inform me about my medical condition. In stark contrast, masks in Maus II represent the disruption of collusion between the wearer and audience. What happens when the sign does not mean to me what it means to you? What is the effect of multivalent identity markers, of traits that do not remain still?

These difficult questions, when asked in tandem with Rankine's cultural criticism in Citizen, take on crucial dimensions. Projection of identity onto another person is a different action than observing a mask being worn. The act of erasure necessary for successful projection should invite critique of the referent perspective-white supremacy continues to be the index, the point of view from which others are seen. Rankine asks us to examine ourselves as a performative culture. To do so, we must first understand how Fanon and Du Bois consider the splitting of the black self to be a requirement for existence within racist referent cultures, resulting in a private self and a public one. The white gaze demands public performance adequate to the racist expectations of identity, and masking is the mode of that performance. The troubling demand for performance of identity, as illustrated by Spiegelman's Maus and Musson's Youngman persona, provides a fertile site for Americans to examine our complicity in reifying racist stereotypes. On the one hand, masks can be useful in projecting outward what we desire others to know about us, thus creating modes for celebration and belonging. On the other, as requirements for visibility masks can enforce the embodiment of racist stereotypes, thereby perpetually commodifying identity. 


\section{Works Cited}

Boucher, Brian. "Ali G with an MFA: Q+A with Hennessy Youngman." Art in America, 24 Mar. 2011, https://www.artnews.com/art-in-america/interviews/hennessey-youngmanyoutube-56192/. Accessed 12 Dec. 2019.

Du Bois, W.E.B. The Souls of Black Folk. Dover Thrift Editions, 1994.

Fanon, Frantz. Black Skin, White Masks. Grove Press, 2008.

Kolář, Stanislav. “Animal Imagery in Kosinski's The Painted Bird and Spiegelman’s Maus.” University of Ostrava, www.phil.muni.cz/angl/thepes/thepes_02_12.pdf. Accessed 14 Feb. 2019.

Loman, Andrew. "Well Intended Liberal Slop': Allegories of Race in Spiegelman's Maus." Journal of American Studies, vol. 40, no. 3, pp. 551-571, 2006. JSTOR, doi: 10.1017/S00218780600212X. Accessed 6 Feb. 2019.

Ma, Sheng-Mei. "Mourning with the (as a) Jew: Metaphor, Ethnicity, and the Holocaust in Art Spiegelman's Maus." Studies in American Jewish Literature, vol. 16, pp. 115-129, 1997. JSTOR, www.jstor.org/stable/41205879. Accessed 2 Mar. 2020.

Mohanty, Chandra Talpade. “Under Western Eyes: Feminist Scholarship and Colonial Discourses." The Post-Colonial Studies Reader, edited by Bill Ashcroft, Gareth Griffiths, and Helen Tiffin, Routledge, 1995, pp. 259-63.

Polenberg, Richard. Hear My Sad Story : the True Tales That Inspired "Stagolee," "John Henry," and Other Traditional American Folk Songs. Cornell University Press, 2015, pp. $149-155$. 
Pollock, Donald. "Masks and the Semiotics of Identity." The Journal of the Royal Anthropological Institute, vol. 1, no. 3, pp. 581-597, 1995. JSTOR, www.jstor.org/stable/3034576. Accessed 14 Feb. 2019.

Rankine, Claudia. Citizen. Graywolf Press, 2014.

Spiegelman, Art. Maus: A Survivor's Tale. Vol. I: My Father Bleeds History. New York, Pantheon Books, 1986.

Spiegelman, Art. Maus: A Survivor's Tale. Vol. II: And Here My Troubles Began. New York, Pantheon Books, 1991.

Staub, Michael E. “The Shoah goes on and on: remembrance and representation in Art Spiegelman's Maus." MELUS, vol. 20, no. 3, 1995, p. 33+. Academic OneFile, www.link.galegroup.com/apps/doc/A18298424/AONE?u=googlescholar\&sid=ANE \&xid=b0011538. Accessed 20 Feb. 2019.

Youngman, Hennessy/Musson, Jason. "ART THOUGHTZ: How To Be A successful Black Artist." YouTube, 7 Oct. 2010. https://www.youtube.com/watch?v=3L_NnX8oj-g. Accessed 12 Dec. 2019. 